Terbit online pada laman web jurnal: http://jurnal.iaii.or.id

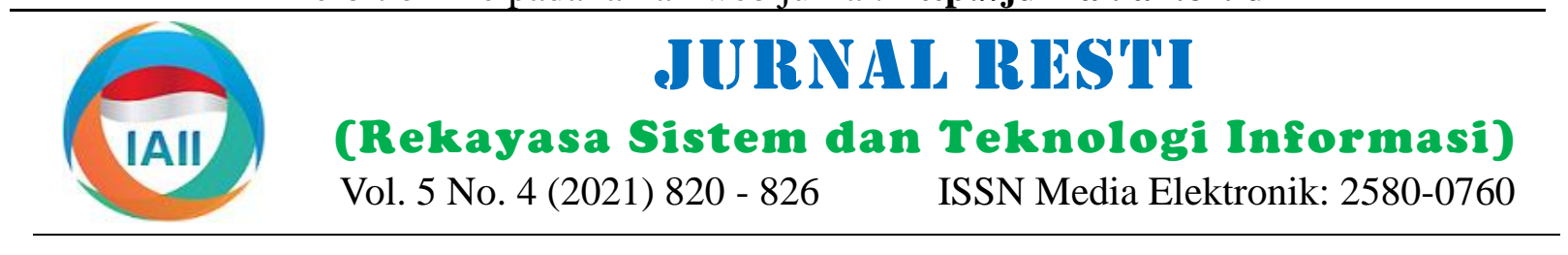

\title{
Algoritma Multinomial Naïve Bayes Untuk Klasifikasi Sentimen Pemerintah Terhadap Penanganan Covid-19 Menggunakan Data Twitter
}

\author{
Yuyun $^{1}$, Nurul Hidayah ${ }^{2}$, Supriadi Sahibu ${ }^{3}$ \\ 1,2,3 Magister Sistem Komputer, STMIK Handayani Makassar \\ *1yuyunwabula@handayani.ac.id, 2nurul.hyh@gmail.com, ${ }^{3}$ supriadi@ handayani.ac.id
}

\begin{abstract}
Currently, the spread of information Covid-19 is spreading rapidly. Not only through electronic media, but this information is also disseminated by user posts on social media. Due to the user text posted is varies greatly, it's needs a special approach to classify these types of posts. This research aims to classify the public sentiment towards the handling of COVID-19. The data from this study were obtained from the social media application i.e., Twitter. This study uses a derivative of the Naïve Bayes algorithm, namely Multinomial Nave Bayes to optimize the classification results. Three class labels are used to classify public sentiment namely positive, negative, and neutral sentiments. The stage starts with text preprocessing; cleaning, case folding, tokenization, filtering and stemming. Then proceed with weighting using the TF-IDF approach. To evaluate the classification results, data is tested using confusion matrix by testing accuracy, precision, and recall. From the test results, it is found that the weighted average for precision, recall and accuracy is 74\%. Research shows that the accuracy of the proposed method has fair classification levels.
\end{abstract}

Keywords: opinion, sentiment, twitter, covid-19, multinomial nä̈ve bayes

\begin{abstract}
Abstrak
Saat ini penyebaran informasi Covid-19 tersebar dengan cepat. Tidak hanya melalui media elektronik, informasi ini juga disebarluaskan melalui postingan user pada media sosial. Karena text postingan masyarakat sangat bervariasi, sehingga perlu pendekatan khusus untuk mengklasifikasi jenis postingan tersebut. Penelitian ini bertujuan untuk mengklasifikasi sentimen masyarakat terhadap penanganan covid-19. Dalam penelitian ini sebanyak 2000 dataset text posting user dianalisis yang bersumber dari aplikasi media sosial Twitter. Penelitian ini menggunakan turunan dari algoritma Naïve Bayes yaitu Multinomial Naïve Bayes untuk mengoptimalkan hasil klasifikasi. Tiga label kelas yang digunakan untuk mengklasifikasi sentiment masyarakat yaitu sentimen positif, negative dan netral. Tahapanya dimulai dengan text preprocessing; cleaning, case folding, tokenisasi, filtering dan stemming. Kemudian dilanjutkan dengan pembobotan menggunakan pendekatan TF-IDF. Untuk mengevaluasi hasil klasifikasi, data diuji menggunakan confusion matrix dengan menguji akurasi, precision dan recall. Dari hasil pengujian diperoleh bahwa weighted average untuk precision, recall dan akurasi sebesar $74 \%$. Penelitian menunjukkan bahwa akurasi metode yang diusulkan Ini memiliki tingkatan cukup baik.
\end{abstract}

Kata kunci: opini, sentiment, twitter, covid-19, multinomial naïve bayes

\section{Pendahuluan}

Saat ini pandemic Covid-19 telah menjadi masalah internasional. Di Indonesia, berbagai upaya dilakukan Situs media sosial Kementerian Kesehatan dan Badan pemerintah dalam penanganan pendemi ini, di antaranya Nasional Penanggulangan Bencana melaporkan bahwa melalui keputusan presiden tentang Gugus Tugas perkembangan kasus positif Covid-19 hingga Percepatan Penanganan Covid-19, Pemberlakuan pertengahan Juli 2020 telah mencapai 78.572 orang, Pembatasan Sosial Berskala Besar (PSBB) hingga dengan peningkatan 1.591 orang dalam 24 jam. penetapan bencana non-alam. Namun, dalam Sementara itu pasien sembuh mencapai 37.636 dengan pelaksanaanya, penanganan Covid-19 masih mengalami peningkatan 947 orang dalam sehari [3]. Akibat berbagai kendala seperti birokrasi, ketidakpatuhan peningkatan ini memicu polemik melalui sentimen sebagian masyarakat terhadap protokol kesehatan[1] masyarakat yang disampaikan melalui media sosial masing-masing. Komentar masyarakat berupa kritik dan

Diterima Redaksi: 20-05-2021 | Selesai Revisi: 24-08-2021 | Diterbitkan Online: 30-08-2021 
saran, serta cuitan secara terus menerus kepada topik kata yang paling sering dibicarakan masyarakat pemerintah kerap dilontarkan melalui akun masing- yaitu amarah, ketakutan, jijik, kesedihan, kejutan, masing pengguna. kegembiraan, dan kepercayaan.

Opini melalui twitter dan komentar inilah yang dapat Dalam pendekatan lain, beberapa studi fokus pada dimanfaatkan untuk melihat sentimen masyarakat performa algoritma text mining dalam mengklasifikasi terhadap kinerja pemerintah dalam penanganan covid- sentiment masyarakat misalnya[14] mengusulkan 19 di Indonesia. Adapun opini-opini tersebut dapat metode SVM, PSO, dan N-Gram dalam mengklasifikasi diklasifikasikan secara positif, negatif mapun netral sentiment public terhadap penanggana covid oleh WHO. dengan pendekatana text mining. Pendekatan dengan Mereka menemukan bahwa kombinasi ketiga metode Text mining dapat memberikan solusi dari permasalahan tersebut megasilkan performa yang baik dengan Akurasi seperti pemrosesan, pengorganisasian/ pengelompokkan 0,75, Presisi 0,71, Recall 0,83, dan AUC 0,84. Demikian dan analisis unstructured data dalam jumlah besar[4]. pula dengan penelitian [15] mengusulkan pendekatan Dalam kasus ini, text postingan yang diolah bersumber machine learning dengan membandingkan tiga metode dari aplikasi media social Twitter, seperti yang yaitu Nä̈ve Bayes, SVM, dan K-NN untuk menganalisis ditampilkan pada gambar 1 .

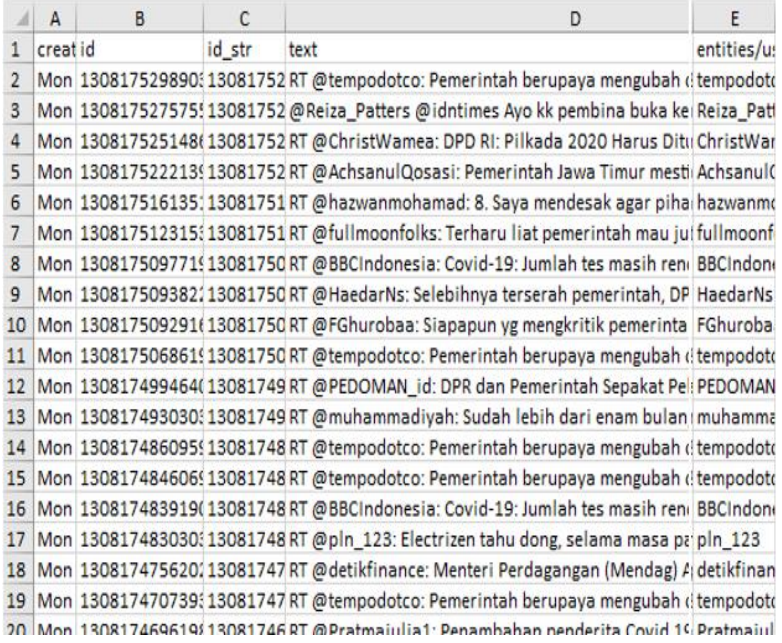

Gambar 1. Data hasil Crawling dari Twitter API sentiment public terhadap presiden dimasa pandemic. Penulis menemukan bahwa metode SVM adalah yang terbaik dengan akurasi 84,58 . Sementara itu penelitian [16] mengusulkan metode Topic Modeling untuk menganalisi sentiment masyarakat. Metode tersebut menghasilkan Tiga topik dominan yaitu protocol Kesehatan, jaga jarak, dan Kesehatan. Terakhir penelitian [17] mengusulkan metode Bidirectional Encoder Representations from Transformers (BERT) dengan membandingkan tiga metode machine learning yaitu logistic regression (LR), support vector machines (SVM), and long-short term memory (LSTM). Mereka menyimpulkan bahwa Model BERT menghasilkan akurasi $89 \%$, dan tiga model lainnya menghasilkan $75 \%, 74.75 \%$, dan $65 \%$.

Namun demikian penenelitin terdahulu focus pada istilah yang masyarakat gunakan terkait dengan covid19 seperti bagaimana emosional masyarakat, dan bagaimana dampak yang ditimbulkan. Dalam penelitian Berbagai penelitian telah dilakukan untuk menganalisis ini fokus kami adalah bagaimana respon masyarakat sentimen publik menggunakan data sosial media terhadap pemerintah dalam penanganan covid di Twitter. Misalnya, penelitian [5] analisis sentimen Indonesia. Dalam mengklasifikasikan sentimen public, wacana pindah ibu kota, tempat wisata [6], ujaran kami membagi label kelas dalam 3 kategori yaitu kebencian [7], komisi pemilihan umum [8], dan Negatif, Positif dan Netral dengan mengusulkan ekspedisi barang [9]. Secara spesifik studi untuk algoritma Multinomial Naive Bayes (MNB). Metode ini menangkap sentiment masyarakat terhadap pandemic dipilih karena dapat melakukan komputasi yang cepat covid-19 misalnya [10] yang mendemonstrasikan dalam mengklasifikasikan dokumen teks serta dapat Twitter data untuk menganalisis informasi covid-19. menyelesaikan permasalahan yang multiple class [18]. Lebih spesifik, penelitian ini menganalisis istilah yang Sementara itu, pemanfaatan data Twitter karena masyarakat gunakan selama pandemic. Mereka kemudahaan dalam aksesan data melalui vasilitas API. menemukan bahwa kata "PSBB", "new normal", Selain itu Data yang hasilkan dari parsing Tweet API "karantina", and "juru bicara Dr. Reisa" adala lima kata dapat menampilkan informasi secara realtime seperti yang mendominasi. Demikian pula penelitian [11] jam, hari, lokasi postingan dan apa yang mereka membagi text opini public menjadi tiga kategori yaitu bicarakan melalui postingan text [19][20].

sedih, senang, atau panik untuk mengekspresikan perasaan masyarakat terhadap keadaan saat ini. 2. Metode Penelitian

Kemudia penelitian [12] mengusulkan pendekatan web scraping untuk menganalis dampak dari covid-19 dan mengasilkan presentase $79 \%$ negative, $11 \%$ netral dan $10 \%$ positif terhadap opini masyarakat. Sementara itu [13] mengusulkan metode Lexicon untuk menganalisis sentiment emosional public. Mereka mengungkap tujuh

\subsection{Alur sistem}

Agar klasifikasi dokumen text lebih terarah, kami membagi Penelitian ini dalam lima tahapan yaitu; tahap pertama mengumpulkan data melalui fasilitas twitter API yang disediakan oleh twitter. Pengambilan data ini 
menggunakan pemrograman Phyton. Tahap kedua adalah text processing, yaitu tahapan mempersiapkan dokumen teks yang tidak terstruktur menjadi data terstruktur yang siap digunakan untuk proses selanjutnya. Tahapan ini terdiri dari Cleansing, tokenizing, Case Folding, Filtering dan Stemming. Tahapa ke Tiga yaitu pembobotan TF-IDF untuk memberi bobot masing-masing kata dalam dokumen. Selanjutnya tahap ke Empat adalah tahapan klasifikasi menggunakan algoritma Multinomial Naive Bayes untuk melihat sentimen Negatif, Positif dan Netral. Dan tahap terakhir adalah pengujian data testing klasifikasi menggunakan confusion matriks.

\subsection{Sumber Data}

Data yang digunakan dalam penelitian ini bersumber dari Twitter API. Data yang di crawling adalah postingan masyarakat yang mengandung kata covid-19. Periode crawling data yaitu antara 25 Agustus - 24 November 2020. Dalam penelitian ini sebanyak 2000 tweet sebagai data set sebagai bahan analisis, di mana 1400 tweets digunakan sebagai data training dan 600 tweet lainnya dijadikan sebagai data testing. Kami menggunakan data yang cukup seimbang untuk mendapatkan akurasi yang baik. Karena dengan kedekatan dan keseimbangan data, akan mempengaruhi hasil klasifikasi, baik itu yang jumlah kelasnya kecil maupun dengan jumlah kelas yang banyak [21][22]. Tabel 3.1 berikut ini menampilkan contoh labeling kategori text postingan twitter.

\subsection{Korpus Data}

Penelitian ini menggunakan pendekatan korpus untuk mengklasifikasi text postingan yang mengandung label kelas positif, netral dan negative. Penentuan masingmasing label kelas basis data korpus seperti yang ditampilkan pada Table 1. Dimana basis data ini berfungsi untuk mencocokan kata dalam text dengan korpus. Sehingga dengan demikian, jika ditemukan ada kata dalam text yang terdapat dalam korpus data maka label kelasnya ditampilkan. Misalnya pada kalimat "Kegagalan penanganan Covid-19 di Indo ini (termasuk PSBB) salah satunya krn tidak ada tindakan tegas pemerintah". Maka untuk menentukan label kalimat diatas apakah positif, netral dan negatif maka kalimat diatas dirubah dalam bentuk kata. Bentuknya adalah sebagai beriktu: "kegagalan" "penanganan" "Covid-19" "Indo" "termasuk" "pspb" "salah" "satunya" "tidak" "ada" "tindakan" "tegas"”pemerintah". Langkah berikutnya dengan mencocokkan kata tersebut dengan basis data korpus. Jika salah satu kata tersebut ditemukan dalam korpus negative maka yang ditampilkan adalah label kelas nagatif begitu seterunya. Ilustrasi pelabelan Tiga kelas tersebut seperti pada gambar 2, dan contoh hasil pelabelan kelas ditunjukan pada Table 2:

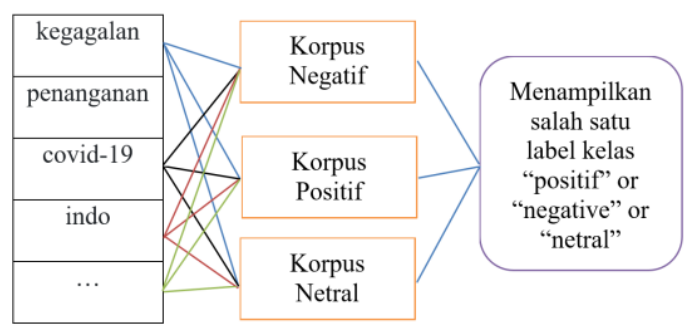

Gambar 2. Proses pembentukan label kelas

Tabel 1 Contoh Korpus untuk label negative, netral dan positif

\begin{tabular}{|c|c|}
\hline $\begin{array}{l}\text { Kelas/ } \\
\text { Label }\end{array}$ & Korpus Data \\
\hline Negatif & $\begin{array}{l}\text { Gagal, remeh, morat-marit, kasus, meninggal, } \\
\text { singgung, ribut, sakit, murtad, aib, mati, sedih, } \\
\text { mogok, derita, ngeri, kurang, salah, wabah, } \\
\text { buruk, kritik, musuh, bingung, egois, telat, virus, } \\
\text { eyel, sengsara, ugal, lalai, bahaya, ngotot, golput, } \\
\text { uring, kesal, pusing, bebal, abai, enggan, bobrok } \\
\text {... }\end{array}$ \\
\hline Netral & $\begin{array}{l}\text { Butuh, kerjasama, mari, bagi, semoga, sepakat, } \\
\text { kata, menerapkan, berlangsung, tampil, muncul, } \\
\text { harus, ditujukan, temuan, deteksi, intropeksi, } \\
\text { minta, ditujukan, standar, rencana, melakukan, } \\
\text { sudah, suruh, bersama, agar, biasa, juga, evaluasi, } \\
\text { arahan, penyuluhan, mohon, harap, wajib, akan, } \\
\text { dorong, info, informasi, target, sapa, } \\
\text { mengingatkan ... }\end{array}$ \\
\hline Positif & $\begin{array}{l}\text { Berkah, bahagia, puji, syukur, sembuh, benar, } \\
\text { kendali, kerjakeras, berhasil, maju, disiplin, bisa, } \\
\text { sehat, bangkit, sayang, aman, ikut, upaya, kuat, } \\
\text { strategis, antisipasi, bersih, patuh, prioritas, } \\
\text { alhamdulillah, mudah, bebas, tahan, lancar, } \\
\text { kreatif, kembang, cepat, usaha, seimbang ... }\end{array}$ \\
\hline
\end{tabular}

Tabel 2. Pelabelan terhadap kelas Negatif, Netral dan Positif

id

RT @NewsMuslimah: MuslimahNews - Benar,

1 sikap pemerintah terlihat abai. Hal itu terkonfirmasi Negatif saat pemerintah enggan melakukan lockdown

Setuju. Kegagalan penanganan Covid-19 di Indo ini

2 (termasuk PSBB) salah satunya krn tidak ada Negatif tindakan tegas pemerintah

Ya gimana ya, dari awal pemerintahnya udah anggap

3 enteng. Ngegampangin covid. Ya udah makin double Negatif aja kasusnya... https://t.co/YlZ3ybAwFo

Tetap Waspada, 70-90 Persen Pasien Covid-19 di

4 Indonesia Tanpa Gejala https://t.co/KJEEU1C4lf Netral \#timesindonesia... https://t.co/NvtzT2HYsI

Siapapun bisa kena COVID19, tua,muda, anak-anak

5 sekalipun, laki-laki , perempuan, di kota maupun di Netral desa. https://t.co/PQN5Br35Ps

@TvOne_News@younaprill @Naunaaty semoga

6 tenaga medis Indonesia mampu bertahan di pandemi Netral seperti ini. https://t.co/jL4RKhrpOo

Seluruh Polri di himbau untuk selalu menjalankan

7 gerakan 3M (memakai masker, menjaga jarak, dan Netral mencuci tangan) https://t.co/P2p36bAepG

RT@Obikurnia1: Apresiasi disampaikan pemerintah

8 pusat pada Jawa Barat dalam keberhasilan Positif penanganan Covid. \#pplhiupdate \#jabarjuara

RT @RadioElshinta: Satgas COVID-19: Kasus

9 kesembuhan di Indonesia lebih tinggi dari rata-rata Positif dunia https://t.co/UJrES5Wod2 https://t.co/En..

10 Saya patuh anjuran pemerintah Pak "DI RUMAH Positif AJA" 


\subsection{Multinomial Naïve Bayes}

Algoritma Multinomial Naive Bayes merupakan salah satu metode pembelajaran probabilistik didasarkan pada teorema Bayes yang digunakan dalam Natural Language Processing (NLP). Algoritma ini bekerja pada konsep term frequency yang berarti berapa kali kata tersebut muncul dalam sebuah dokumen. Model ini menjelaskan dua fakta yaitu apakah kata tersebut muncul dalam sebuah dokumen atau tidak serta frekuensinya kemunculan dalam dokumen. Multinomial Nä̈ve Bayes dapat diformulasikan sebagai berikut [23], rumus 1 .

$$
P(p \mid n) \propto P(p) \prod_{1 \leq \mathrm{k} \leq \mathrm{nd}} P\left(t_{\mathrm{k}} \mid p\right)
$$
dimana $\mathrm{P}(\mathrm{tk} \mid \mathrm{p})$ : probabilitas munculnya dokumen text dengan kata lain adalah proses untuk membagi teks yang (tk), $\mathrm{n}$ adalah jumlah dokumen dan $\mathrm{p}$ adalah polaritas. berasal dari kalimat atau paragraf menjadi bagianKemudian untuk menghitung polaritasnya atau bagian tertentu. Berikut adalah contoh benerapa hasil dokumen yang mempunyai kemiripan dirumuskan dari tokenisasi yang dilakukan pada data teks: sebagai berikut, rumus 2 .

$$
P\left(t_{\mathrm{k}} \mid p\right)=\frac{\operatorname{count}\left(t_{\mathrm{k}} \mid p\right)+1}{\operatorname{count}\left(t_{\mathrm{p}}\right)+|V|}
$$

\begin{tabular}{|c|c|}
\hline Sebelum tokenisasi & Setelah tokenisasi \\
\hline $\begin{array}{l}\text { Setuju. Kegagalan penanganan } \\
\text { Covid-19 di Indo ini (termasuk } \\
\text { PSBB) salah satunya krn tidak } \\
\text { ada tindakan tegas }\end{array}$ & $\begin{array}{l}\text { Setuju. kegagalan penanganan } \\
\text { covid-19 di indo ini (termasuk } \\
\text { pspb) salah satunya krn tidak ada } \\
\text { tindakan tegas }\end{array}$ \\
\hline
\end{tabular}
yang memiliki polaritas p dan jumah (tp) beku jumlah token yang ada di artikel berita dengan polaritas $\mathrm{p}$.

\subsection{Validasi Model}

Dalam melakukan pengujian terhadap datah latih, perlu dilakukan evaluasi terhadap hasil prediksi. Dalam makalah ini, kami menggunakan Confusion Matriks untuk menguji hasil testing dengan memperhatikan akurasi, presisi, dan recall. Untuk menghitung akurasi
pada confusion matriks menggunakan persamaan 3 [24].

Accuracy $=\mathrm{TP}+\mathrm{TN} / \mathrm{TP}+\mathrm{TN}+\mathrm{FP}+\mathrm{FN}$

$\mathrm{TP}$; true positive, $\mathrm{FN}$; false negative, dan FP: false positive and $\mathrm{TN}$; true negative

\section{Hasil dan Pembahasan}

\subsection{Text Preprocessing}

Data yang diperoleh dari hasil crawling masih berbentuk data mentah. Melalui text preprocessing, data-data tersebut perlu ditransformasi ke format yang dapat dimengerti. Berikut adalah tahapan dalam preprocessing data: Tahapan pertama yaitu Case Folding, Teknik ini mengubah semua huruf dalam dokumen menjadi huruf kecil. Hanya huruf 'a' sampai dengan ' $z$ ' yang diterima. Berikut ini beberapa data hasil dari Case Folding yaitu menjadikan kata yang berhuruf kapital menjadi huruf kecil. Dalam penelitian ini kami mengambil sampel sebagai berikut, tabel 3 .

Ketiga adalah Filtering dan Cleansing yaitu proses membersihkan tweets dari kata yang tidak diperlukan untuk mengurangi noise. Kata yang dihilangkan bisa berupa karakter HTML, katakunci, hashtag, username, url, dan email. Kemududian untuk tahap Filtering adalah tahap mengambil kata-kata penting dari hasil token. Stoplist/ stopword adalah kata-kata yang tidak deksriptif yang dapat dibuang dalam pendekatan bag-of-words.

Tabel 3. Tabel case folding

\begin{tabular}{ll}
\hline Sebelum case folding & Setelah case Folding \\
\hline Setuju. Kegagalan penanganan & Setuju. kegagalan penanganan \\
Covid-19 di Indo ini (termasuk & $\begin{array}{l}\text { covid-19 di indo ini (termasuk } \\
\text { pspb) salah satunya krn tidak }\end{array}$ \\
PSBB) salah satunya krn tidak & $\begin{array}{l}\text { ada tindakan tegas } \\
\text { ada tindakan tegas }\end{array}$
\end{tabular}

Kedua tahap Tokenizing yaitu proses pemotongan string nput berdasarkan tiap kata yang menyusunnya. Atau

Tabel 4. Tabel tokenisasi

Tahap ke Empat Stemming adalah tahap mencari root kata dari tiap kata hasil Filtering. Pada tahap ini dilakukan proses pengembalian berbagai bentukan kata ke dalam makna dasar. Penggunaan metode stemming dibandingkan dengan metode lain karena pendekatan ini menghasilkan tingkat akurasi yang tinggi serta mempunyai tinggkat error yang rendah dibandingkan dengan metode lain [25]

\subsection{Hasil Klasifikasi Algoritma}

Sebelum tahapan klasifikasi algoritma, data-data diolah menggunakan algoritma TF-IFD. TF (Term Frequency) adalah frekuensi dari kemunculan sebuah term dalam dokumen yang bersangkutan. Semakin besar jumlah kemunculan suatu term (TF tinggi) dalam dokumen, semakin besar pula bobotnya atau akan memberikan nilai kesesuaian yang semakin besar. Kemudian untuk metode IDF (Inverse Document Frequency) sendiri merupakan sebuah perhitungan dari bagaimana term didistribusikan secara luas pada koleksi dokumen yang bersangkutan. IDF menunjukkan hubungan ketersediaan sebuah term dalam seluruh dokumen. Semakin sedikit jumlah dokumen yang mengandung term yang dimaksud, maka nilai IDF semakin besar. Berikut adalah contoh perhitungan TF-IDF, di mana rumus dari TF-IDF adalah : rumus 4.

$W i j=t f i j x \log (D d f)+1$

Pada gambar 3. menampilkan hasil Term Frekuensi berdasarkan perhitungan IDF dalam keseluruhan dokumen. Nilai yang dihasilkan pada table 4 menujukan 
bobot masing-masing term dokumen. Setelah pembobotan TF-IDF, sistem juga menyediakan kolom test data untuk memasukkan kalimat yang akan diprediksi oleh sistem. Prediksi yang dihasilkan berupa pengkategorisasian negatif, positif atau netral.

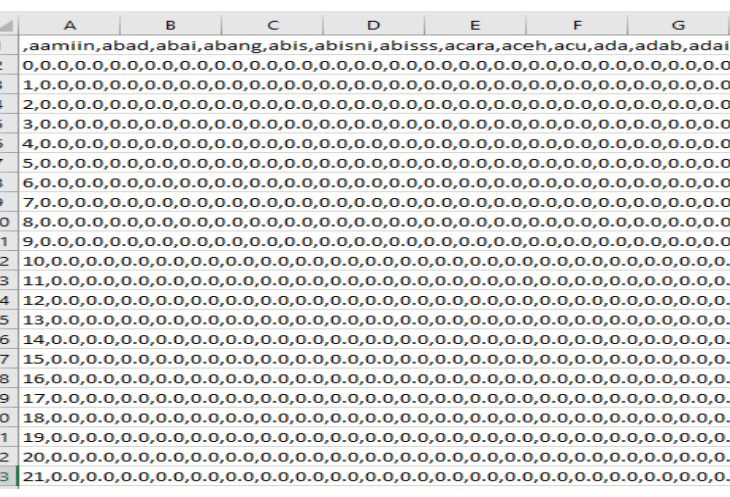

Gambar 3. Hasil faktorisasi TF-IDF terhadap data testing

Pada Gambar 4 menampilkan hasil prediksi. Adapun contoh hasil prediksinya adalah "langkah pemerintah sudah sangat baik dan benar cara paling ampuh untuk memerangi pandemi" sebagai kalimat yang mengandung sentimen 'Positif'.

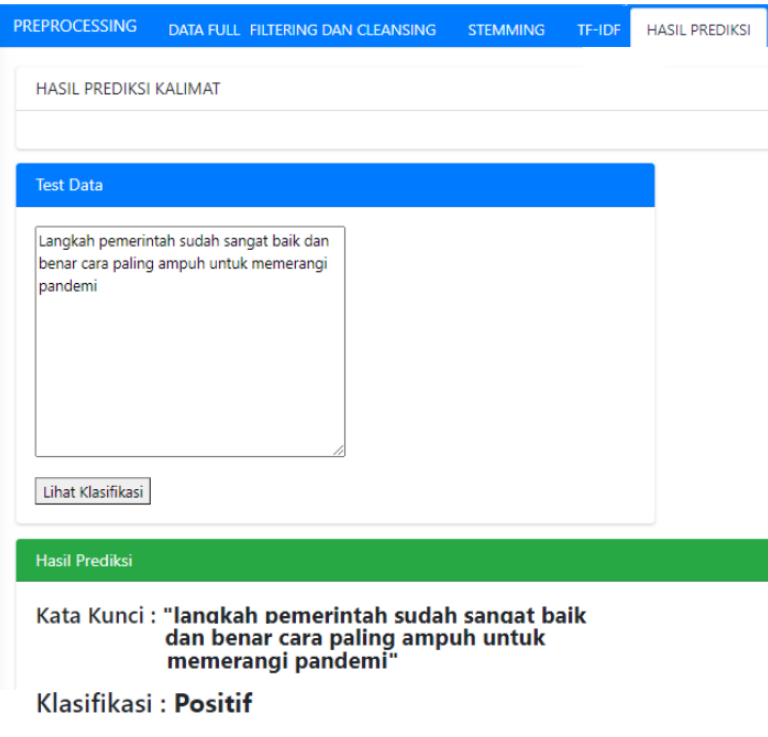

Gambar 4. Hasil prediksi terhadap data testing

\subsection{Hasil Pengujian Algoritma Naïve Bayes}

Dalam simulasi ini kami melakukan testing terhadap 600 postingan user terkait dengan penanganan covid-19. Dengan algoritma yang diusulkan, kemudian diklasifikasikan postingan ke dalam tiga kelas yaitu kelas Negatif, Positif dan Netral. Untuk mengevaluasi hasil prediksi pendekatan confusion matriks digunakan yaitu pengukuran terhadap precision, recall dan akurasi.

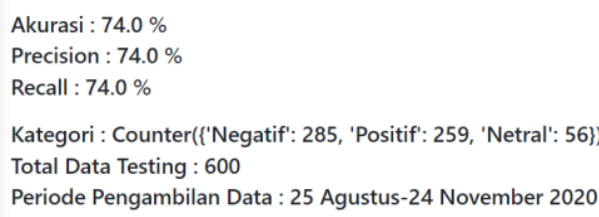

Gambar 5. Pengujian terhadap Akurasi, Precision dan Recall

Dari hasil pengujian algoritma Multinomial Naïve Bayes diketahui bahwa performance algoritma memiliki akurasi rata-rata sebesar $74 \%$, precision sebesar $74 \%$ dan recall sebesar $74 \%$ dalam memprediksi sentimen terhadap penanganan Covid di Indonesia. Karena pencarian dokumen teks menggunakan query yang berurutan, sehingga hasil pengujian terhadap Tiga parameter diatas bernilai sama. Berikut ini merupakan gambar grafik confusion matrix system.

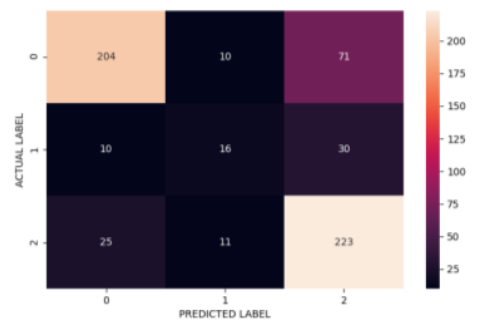

Gambar 6. Tampilan Grafik Confusion Matrix

Terdapat tiga kelas yang menjadi output penelitian ini sehingga pengujian dengan confusion matrix menggunakan skala $3 \times 3$. Pada confusion matrix di atas, kelas Negatif di lambangkan dengan angka 0, kelas Netral dilambangkan dengan angka 1 dan kelas Positif dilambangkan dengan angka 2. Berikut ini merupakan perhitungan manual confusion matrix untuk menghitung akurasi, precision dan recall

Tabel 5. Tabel perhitungan manual confusion matrix

\begin{tabular}{ccccc}
\hline Actual & $\begin{array}{c}\text { Prediksi } \\
\text { Positif }\end{array}$ & $\begin{array}{c}\text { Prediksi } \\
\text { Negatif }\end{array}$ & $\begin{array}{c}\text { Prediksi } \\
\text { Netral }\end{array}$ & $\begin{array}{c}\text { Total } \\
\text { Actual }\end{array}$ \\
\hline Positif & 223 & 25 & 11 & 259 \\
Negatif & 71 & 204 & 10 & 285 \\
Netral & 30 & 10 & 16 & 56 \\
Total Prediksi & 324 & 239 & 37 & 600 \\
\hline
\end{tabular}

Berdasarkan Tabel 5 di atas, pengujian confusion matrix dengan skala $3 \times 3$ diperoleh nilai TP 223 untuk kelas Positif, 204 TP untuk kelas Negatif dan 16 TP untuk kelas Netral. Di mana TP sendiri adalah jumlah dari sebuah kelas True yang diprediksi. Sedangkan TN adalah jumlah dari sebuah kelas False yang juga diprediksi oleh sistem sebagai kelas False. False Positif adalah kelas True yang salah diprediksi oleh sistem sebagai kelas False, dan terakhir False Negatif adalah kelas False yang salah diprediksi oleh sistem sebagai kelas True. Selanjutnya proses dilanjutkan dengan perhitungan nilai precision dengan menguji seberapa

DOI: https://doi.org/10.29207/resti.v5i4.3146

Creative Commons Attribution 4.0 International License (CC BY 4.0) 
persen ke Tiga kelas tersebut yang benar Negatif, Netral dan Positif dari keseluruhan data? Adapun perhitungan dan Positif dari keseluruhan kelas yang diprediksi? manual untuk akurasi adalah

Perhitungan precision menggunakan persamaan 5.

\section{Precision $=\mathrm{TP} /(\mathrm{TP}+\mathrm{FP})$}

Sehingga Weighted Avg Precision = Jumlah dari Total Actual (6)

Kelas / Jumlah Data*Precision $259 / 600 * 0,6883)+(285 / 600 * 0,8536)+$ $(56 / 600 * 0,4324)=0,7429$

Tabel 6. Tabel hasil perhitungan manual precision

\begin{tabular}{ccc}
\hline Kelas & Proses & Hasil \\
\hline Class Positif & $223 / 324$ & 0,6883 \\
Class Negatif & $204 / 239$ & 0,8536 \\
Class Netral & $16 / 37$ & 0,4324
\end{tabular}

Berdasarkan tabel 6 diatas, precision ditentukan berdasarkan pembagian antara jumlah prediksi benar dengan total keseluruhan. Hasil yang diperoleh yaitu kelas Positif memiliki precision sebesar 0,6883, kelas Negatif sebesar 0,8536 dan precision kelas Netral adalah 0,4324. Hal karena hasil olahan kelas netral memiliki temuan data lebih sedikit dibandingkan dengan kelas positif maupun negative sehingga mempengaruhi nilai presisi. Kemudian untuk rata-rata precision yang menggunakan Weighted Average ditemukan adalah 0,7429 atau dalam persentase $74 \%$. dilanjutkan dengan menghitung recall. Positif, Negatif dan Netral terhadap kondisi Covid-19. Pengujian ini akan menjawab pertanyaan seberapa Prediksi yang dilakukan dengan metode Multinomial persen ke Tiga kelas tersebut yang benar negatif, netral Nä̈ve Bayes mengasilkan akurasi sebesar 74\%, dan positif dari keseluruhan kelas yang sebenarnya? precision sebesar $74 \%$ dan juga recall sebesar $74 \%$. Hasil perhitungan recall dapat dilihat pada tabel berikut Sehingga diperoleh nilai AUC adalah 0,74. Ini ini.

Tabel 7. Tabel hasil perhitungan manual recall

\begin{tabular}{ccc}
\hline Kelas & Proses & Hasil \\
\hline Class Positif & $223 / 259$ & 0,8610 \\
Class Negatif & $204 / 285$ & 0,7158 \\
Class Netral & $16 / 56$ & 0,2857 \\
\hline
\end{tabular}

Sehingga diperoleh

Weighted Avg Recall $=(259 / 600 * 0,8610)$

$(285 / 600 * 0,7158)+(56 / 600 * 0,2857)=0,7383$

Berdasarkan tabel 7, untuk menghitung recall adalah dengan pembagian antara jumlah klasifikasi yang benar dengan total keseluruhan aktual. Sehingga Recall kelas Positif memiliki precision sebesar 0,8610 , kelas Negatif sebesar 0,7158 dan precision kelas Netral adalah 0,2857. Kemudian untuk rata-rata dengan Weighted Average diperoleh sebesar 0,7383 atau dalam persentase adalah $74 \%$.

Kemudian untuk akurasi adalah menghitung seberapa persen ke Tiga kelas tersebut yang benar Negatif, Netral [3]

$$
\begin{gathered}
\text { Akurasi }=\text { Total Correctly Clasified/Actual } \\
443 / 600=0.7383
\end{gathered}
$$

Diketahui rumus akurasi adalah total klasifikasi benar dibagi dengan jumlah data aktual, sehingga diperoleh 0,7383 atau dalam persentasi adalah $74 \%$. Setelah itu, dihitung nilai AUC yaitu dengan (Rata-rata Recall + Rata-rata Specificity)/2. Sehingga hasilnya adalah: $\mathrm{AUC}=(0,6208+0,8563) / 2=0,7386$

Berdasarkan pengujian terhadap tiga parameter yaitu precision, recall dan akurasi terhadap Tiga kelas yaitu positif, negative dan netral diperoleh bahwa ukurasi data dipengaruhi oleh data uji. Semakin banyak jumlah data yang di uji maka semakin tinggi tingkat akurasi prediksi. $74 \%$ akurasi, $74 \%$ precission dan $73 \%$ recall data yang diperoleh menandakan bahwa sekitar $26 \%$ data dengan algoritma ini tidak tercover untuk semua jenis kelas. Dengan tingkat kerumitan tinggi pada pengolahan data dalam bentuk text, sehingga dapat disimpulkan bahwa algoritma ini mampu bekerja baik karena dapat membangkitkan dokumen yang relevan terhadap keseluruhan dokumen.

\section{Kesimpulan}

Berdasarkan analisis diatas disimpulkan bahwa sistem dapat melakukan kategorisasi sentimen teks dalam kelas tingkatan fair classification atau (nilai diagnostik sedang/cukup baik).

Untuk penelitian selanjutnya penggunaan sosial media lain perlu dipertimbangkan. Kemudian, perlu ditambahkan algoritma lain untuk membantu kinerja algoritma Multinomial Naïve Bayes dalam proses pengklasifikasian sentimen, khususnya karena peneliti + melihat bahwa Multinomial Naïve Bayes melakukan learning per satu kata maka untuk penelitian berikutnya diharapkan algoritma dapat memperhatikan lebih dari satu kata atau bahkan per satu kalimat.

\section{Daftar Rujukan}

] D. R. Buana, “Analisis Perilaku Masyarakat Indonesia dalam Menghadapi Pandemi Virus Corona (Covid-19) dan Kiat Menjaga Kesejahteraan Jiwa," SALAM J. Sos. dan Budaya Syar-i, vol. 7, no. 3, 2020, doi: 10.15408/sjsbs.v7i3.15082.

[2] A. Dhita, K. Amrynudin, and R. Katharin, "Birokrasi Dan Kebijakan Percepatan Penanganan Covid-19," Puslit BKD, vol. XII, no. 9, pp. 25-30, 2020. per tanggal 14 Juli 2020 pukul 12.00 WIB," Facebook Page Kemeterian Kesehatan, 2020.
K. Kesehatan, "Update Perkembangan COVID-19 di Indonesia 
[4] F. Nurhuda, S. Widya Sihwi, and A. Doewes, "Analisis Sentimen Masyarakat terhadap Calon Presiden Indonesia 2014 berdasarkan Opini dari Twitter Menggunakan Metode Naive Bayes Classifier," J. Teknol. Inf. ITSmart, vol. 2, no. 2, p. 35, 2016, doi: [16] 10.20961/its.v2i2.630.

[5] P. Arsi, R. Wahyudi, and R. Waluyo, "Optimasi SVM Berbasis [17] PSO pada Analisis Sentimen Wacana Pindah Ibu Kota Indonesia," J. RESTI (Rekayasa Sistem. dan Teknologi. Informasi), vol. 5, no. 2,pp. 231-237, 2021, doi: 10.29207/resti.v5i2.2698.

[6] R. Sistem et al., "Sentimen dan Pemodelan Topik Pariwisata Lombok," J. RESTI(Rekayasa Sistem dan Teknologi. Informasi)., vol. 1, no. 10, pp. 123-131, 2021

[7] Oryza Habibie Rahman, Gunawan Abdillah, and Agus Komarudin, "Klasifikasi Ujaran Kebencian pada Media Sosial Twitter Menggunakan Support Vector Machine," J. RESTI (Rekayasa Sistem. dan Teknologi. Informasi), vol. 5, no. 1, pp. 1723, 2021, doi: 10.29207/resti.v5i1.2700.

[8] I. Santoso, W. Gata, and A. B. Paryanti, "Penggunaan Feature Selection di Algoritma Support Vector Machine untuk Sentimen Analisis Komisi Pemilihan Umum," J. RESTI (Rekayasa Sistem. dan Teknologi. Informasi), vol. 1, no. 10, pp. 5-11, 2019.

[9] Sharazita Dyah Anggita and Ikmah, "Komparasi Algoritma Klasifikasi Berbasis Particle Swarm Optimization Pada Analisis Sentimen Ekspedisi Barang," J. RESTI (Rekayasa Sistem. dan Teknologi Informasi), vol. 4, no. 2, pp. 362-369, 2020, doi: 10.29207/resti.v4i2.1840.

[10] E. E. Pratama and R. L. Atmi, "A Text Mining Implementation Based on Twitter Data to," J. Comput. Soc., vol. 1, no. 1, pp. 91$100,2020$.

[11] A. K. Fauziyyah, "Analisis Sentimen Pandemi Covid19 Pada Streaming Twitter Dengan Text Mining Python," J. Ilm. SINUS, vol. 18, no. 2, p. 31, 2020, doi: 10.30646/sinus.v18i2.491.

[12] Robi Kurniawan and A. Aulia, "Analisis Sentimen Masyarakat Terhadap Virus Corona Berdasarkan Opini Dari Twitter Berbasis Web Scraper," Jurnal INSTEK (Informatika Sains dan Teknologi), [24] vol. 5, no. 1. p. 67, 2020, doi: 10.24252/instek.v5i1.13686.

[13] Aribowo Agus Sasmito and S. Khomsah, "Implementation Of Text Mining For Emotion Detection Using The Lexicon Method (Case Study: Tweets About Covid-19)," Telematika, vol. 18, no. 1, p. 49, 2021, doi: 10.31315/telematika.v18i1.4341.

[14] D. Y. L. Noor Hafidz, "Klasifikasi Sentimen pada Twitter Terhadap WHO Terkait Covid-19 Menggunakan SVM, N-Gram, PSO," vol. 1, no. 10, pp. 3-4, 2021.

[15] S. Hikmawan, A. Pardamean, and S. N. Khasanah, "Sentimen
Analisis Publik Terhadap Joko Widodo terhadap wabah Covid-19 menggunakan Metode Machine Learning," J. Kaji. Ilm., vol. 20, no. 2, pp. 167-176, 2020, doi: 10.31599/jki.v20i2.117.

6] C. Prianto and N. H. Harani, "Sentiment Analysis of Covid-19 As A Social Media Pandemic," vol. 4, no. 36, pp. 509-517, 2020.

N. Chintalapudi, G. Battineni, and F. Amenta, "Sentimental Analysis of COVID-19 Tweets Using Deep Learning Models," Infect. Dis. Rep., vol. 13, no. 2, pp. 329-339, 2021, doi: 10.3390/idr13020032.

8] P. Studi, T. Informatika, F. I. Komputer, and U. B. Jaya, "Perbandingan Kinerja Variasi Naive Bayes Multivariate Bernoulli dan Naive Bayes Multinomial dalam Pengklasifikasian," vol. 2, pp. 108-125, 2020.

9] Yuyun, F. A. Nuzir, and B. J. Dewancker, "Dynamic land-use map based on twitter data," Sustain., vol. 9, no. 12, pp. 1-20, 2017, doi: $10.3390 / \mathrm{su} 9122158$.

0] N. Umar, Yuyun, Hazriani, and Herman, "Personal popular name identification through twitter data," Int. J. Adv. Trends Comput. Sci. Eng., vol. 9, no. 5, pp. 8184-8190, 2020, doi: 10.30534/ijatcse/2020/182952020.

1] F. Afshoh, "Analisa Sentimen Menggunakan Naïve Bayes Untuk Melihat Persepsi Masyarakat Terhadap Kenaikan Harga Jual Rokok Pada Media Sosial Twitter,” Universitas Muhammadiya Surakarta, 2017.

22] I. F. Rozi, E. N. Hamdana, and M. B. I. Alfahmi, "Pengembanagan Aplikasi Analisis Sentimen Twitter Menggunakan Metode Naive Bayes Classifier (Studi Kasus SAMSAT Kota Malang)," $J$. Inform. Polinema, vol. 4, pp. 149-154, 2018.

] G. Singh, B. Kumar, L. Gaur, and A. Tyagi, "Comparison between Multinomial and Bernoulli Naïve Bayes for Text Classification," 2019 Int. Conf. Autom. Comput. Technol. Manag. ICACTM 2019, no. May 2020, pp. 593-596, 2019, doi: 10.1109/ICACTM.2019.8776800

4] M. Y. H. Setyawan, R. M. Awangga, and S. R. Efendi, "Comparison Of Multinomial Naive Bayes Algorithm And Logistic Regression For Intent Classification In Chatbot," Proc. 2018 Int. Conf. Appl. Eng. ICAE 2018, no. October, pp. 1-5, 2018, doi: 10.1109/INCAE.2018.8579372.

[25] Rianto, A. B. Mutiara, E. P. Wibowo, and P. I. Santosa, "Improving the accuracy of text classification using stemming method, a case of non-formal Indonesian conversation," Journal of Big Data, vol. 8, no. 1. 2021, doi: 10.1186/s40537-021-00413-

DOI: https://doi.org/10.29207/resti.v5i4.3146

Creative Commons Attribution 4.0 International License (CC BY 4.0) 